\title{
The foreign policy of Qatar: From a mediating role to an active one
}

\author{
La politica exterior de Catar: \\ de un papel mediador a un papel activo
}

IGNACIO ÁLVAREZ-OSSORIO

Universidad Complutense de Madrid

LETICIA RODRÍGUEZ GARCÍA

Universidad de Granada

\section{Cómo citar/Citation}

Álvarez-Ossorio, I. y Rodríguez García, L. (2021). The foreign policy of Qatar: From a mediating role to an active one. Revista Española de Ciencia Política, 56, 97-120. Doi: https://doi.org/10.21308/recp.56.04

\begin{abstract}
The aim of this article is to examine how the process of foreign policy decision-making affects the conduct of states in the international system and how states respond to external threats according to internal factors, notably elite threat perceptions and the capacity of institutions to mobilize power. Despite its small size and population, Qatar has achieved enormous regional projection in the last decades. Our hypothesis is that the Arab Spring forced Qatar and the rest of the monarchies in the Gulf to restructure their foreign policies. The mediator-integrator role that Doha had played till then gave way to a more active, independent role in which the tools of hard power gradually replaced those of previous soft power. These changes aggravated tensions with Saudi Arabia and the United Arab Emirates which, in 2017, decided to impose a blockade on Qatar.
\end{abstract}

Keywords: Qatar, Arab Spring, Al Jazeera, Iran, Saudi Arabia.

\section{Resumen}

El objetivo de este artículo es examinar cómo afecta el proceso de toma de decisiones en la política exterior a la conducta de los Estados en el sistema internacional y cómo responden estos a las amenazas externas en función de factores internos, en especial las percepciones de amenaza y la capacidad de las instituciones para movilizar poder. A pesar de su escaso tamańo y reducida población, Catar ha alcanzado en las últimas décadas una enorme proyección regional. Nuestra hipótesis es que la Primavera Árabe obligó a Catar y al resto de monarquías de la región a 
reestructurar su política exterior. El rol mediador-integrador desempeñado hasta entonces por Doha dejó paso a un rol activo-independiente en el que las herramientas del hard power sustituyeron paulatinamente a las del soft power precedente. Este cambio agravó las tensiones con Arabia Saudí y Emiratos Árabes Unidos, que en 2017 decidieron imponer un bloqueo sobre Catar.

Palabras clave: Catar, Primavera Árabe, Al Jazeera, Irán, Arabia Saudí.

\section{INTRODUCTION}

The purpose of this article is to analyze Qatar's foreign policy using the theoretical framework of Foreign Policy Analysis (FPA), a branch of International Relations that attempts to determine how the decision-making mechanism works and how states respond to external threats according to internal factors, notably elite threat perceptions and the capacity of institutions to mobilize power. FPA focuses on "the conduct and practice of relations between different actors, primarily states, in the international system [...]. At the heart of the field is an investigation into decision making, the individual decision makers, processes and conditions that affect foreign policy and the outcomes of these decisions" (Alden and Aran, 2017: 3).

Foreign policy has been defined in numerous ways by various authors in international relations. Chris Alden and Amnon Aran define the study of foreign policy as "ever-changing story of how states, institutions and peoples engage with one another within a dynamic international system" (ibid.: 1). Rafael Calduch defines foreign policy as "that part of general policy formed by the set of decisions and actions through which the objectives are defined and the means of a State are used to generate, modify or suspend its relations with other actors in international society" (1993: 3). Jean Fréderic Morin and Jonathan Paquin go beyond, defining foreign policy as "a set of actions or rules governing the actions of an independent political authority deployed in the international environment" (2018: 3). Both authors make special reference to the independence of these actions, as the authority exercising them rests with the states, which are sovereign.

The Foreign Policy Analysis is the study of "conduct and practice of relations between different actors, primarily states, in the international system" (Alden and Aran, 2017: 2-3). Diplomacy, trade and cultural exchanges or intelligence all of them are a part of the Foreign Policy. Research in foreign policy analysis focuses on decision-making, the actors involved in this process, the conditions that affect foreign policy, the role of the elites and so on. The fields of study in foreign policy analysis are diverse and range from sociology to psychology through economics or public administrations; these being just a few examples. This interdisciplinarity makes the analysis of foreign policy, as defined by Morin and Paquin "multilevel, multidisciplinary and multicausal" (2018: 7-8).

Traditionally, FPA finds interest "in decisions taken by human decisionmakers in positions of authority to commit the resources of the nation-state, though it is quite 
possible to analyse decisionmakers who do not hold such positions" (Hudson, 2014: 4). Therefore, the FPA put the focus on "the foreign policy process, as opposed to foreign policy outcomes, is predicated on the belief that closer scrutiny of the actors, their motivations, the structures of decision making and the broader context within which foreign policy choices are formulated would provide greater analytical purchase than could be found in utilising an International Relations approach" (Alden and Aran, 2017: 3).

FPA recognizes a close relationship between domestic policy and foreign action ${ }^{1}$. Based on this premise, this article aims to consider the domestic, regional and international dimensions that have had a decisive bearing on the development and implementation of Qatar's foreign policy. Our purpose is to answer the question about how the process of foreign policy decision-making affects the conduct of states in the international system and the relationship between actors and foreign policy.

Our article makes use of role theory to explain the behavior of States in the international system. Role theory, applied to foreign policy analysis, establishes how foreign policy has certain purposes and ends up being shaped by institutions and their structures (Aggestam, 2006: 25). According to Holsti, the application of role theory to FPA should consider four dimensions. Firstly, role performance, which addresses the attitudes, decisions and actions taken by political actors and are conditioned by various factors such as expectations, values or traditions. Secondly, national role conceptions, which take into account the perception and aspirations of a State in the international system in terms of its location, resources, capacities, values, ideology, etc. Thirdly, role prescriptions, which are externally derived, including the structure of the international system, international legality, the rules set out in international treaties, etc, and tend to determine how much room for manoeuvre actors have. Fourthly, and finally, when taking decisions and implementing them, decision makers should take into account the status of the State they represent (Holsti, 1970: 240-244). From this theoretical perspective, we will analyze the changes Qatar's foreign policy has undergone in the last decades.

For some authors, such as Evans (2001), role theory is incompatible with authoritarian regimes. In our opinion, it is necessary to make every effort to further investigate role theory in non-democratic systems. As it will be shown below, over the years Qatar has been acquiring different roles that have defined its foreign policy. This has been possible largely thanks to Emir Khalifa bin Hamad Al Thani's charisma and vision and a homogeneous society, with a public opinion that supports his government's decisions. Some researches on public opinion in these types of regimes highlights its influence and the partisan use by these leaders to gain legitimacy (Cantir and Karboo, 2012: 5).

1. As Holsti points out, "in international politics, then, the fact of sovereignty implies that foreign policy decisions and actions (role performances) derive primarily from policymakers' role conceptions, domestic needs and demands, and critical events or trends in the external environment" (1970: 244). 
Despite being a small country that could easily have found itself relegated to playing a minor international role, the Qatari authorities have chosen instead to put Qatar on the map, which has enabled it to gain considerable influence in the Gulf and Middle East. As Mehran Kamrava points out, "[it has] transformed itself from a poor backwater and a practical vassal state of Saudi Arabia a few decades ago into one of the region's richest, most recognizable and highly influential states [...]. Qatar has accumulated its power through a track record of high-profile mediations, generous spending and strategically commercial investments across the globe, doses of soft power (through Al Jazeera), and a hyperactive diplomacy" (Kamrava, 2013: 3, 5). Kamrava coined the term "subtle" power to define this foreign policy, which is a combination of military security (provided by the United States via the Al Udeid military base), wealth (which gives it enhanced domestic autonomy and leverage in co-opting domestic actors, and allows it to invest heavily overseas), the Qatar brand (which portrays Qatar as a stable, progressive, dynamic, and investment-friendly country) and active diplomacy (which enhances the country's stature and influence) (ibid.: 9-10).

\section{QATAR'S FOREIGN POLICY AFTER INDEPENDENCE (1971-1995)}

Qatar's conception of its role is determined by a series of factors, which include its geographical location, natural resources and demographic characteristics and their interpretation by Qatari elites, which have conditioned its relationship with the regional environment and the international system. As Rosemarie Said Zahlan points out, "the location and geographical features of Qatar have played a predominant role in the shaping of its political and social characteristics" (1979: 13); hence the pressing need to forge solid alliances with international powers in order to guarantee its survival.

Despite its small size (11,586 square kilometres), Qatar's geostrategic position makes it a key player in the Arab/Persian Gulf. Notwithstanding its economic strength, it should not be forgotten that Qatar is also extremely vulnerable because it is one of the smallest and least populated countries in the Gulf; as a matter of fact, one of the priorities of Qatari foreign policy is to maintain stability in the region, which requires ensuring that a certain balance is maintained between the two main regional powers: Saudi Arabia and Iran. As Abdallah Baabood has pointed out, "its small size in terms of territory and population, and its geographical location between two large competing and antagonistic regional powers, creates a chronic vulnerability which leads Qatar's leadership to endlessly hedge its bets and play a careful balancing act in order to safeguard the sustainability of the state and the survival of the dynasty in power" (Baabood, 2017: 3).

Like other neighbouring countries, Qatar has an abundance of natural resources that have enabled it not only to guarantee social peace at home, but also to implement an ambitious foreign policy. This energy wealth has made it possible to mobilize significant resources that have been used as a tool to increase its influence in the 
region. The country holds the third largest natural gas reserves in the world. The nation's dependence on hydrocarbons is obviously risky, since they currently account for $85 \%$ of exports and $50 \%$ of GDP, which is why a variety of measures have been adopted in the last two decades in an attempt to diversify the economy (International Monetary Fund, 2019). The Qatar Investment Authority (QIA) was set up in 2005, and by 2020 , it managed assets of 295 billion dollars and had become the sixth largest sovereign wealth fund in the world (Middle East Monitor, 2020). In 2008, the ambitious Qatar National Vision 2030 programme was approved. Its main remit was to help chart the transition from a hydrocarbon-based economy to a knowledge economy, and its key objective was "to transform Qatar into an advanced society capable of sustainable development" based on "human, social, economic and environmental development" (Qatar. General Secretariat For Development Planning, 2008).

Like Kuwait and the United Arab Emirates (UAE), Qatar has a small population and a large number of foreign workers. Only 320,000 of the emirate's 2,875,000 inhabitants have Qatari nationality, the majority of whom practice Sunni Islam. The population, which numbered only 110,000 in 1971 when the country achieved independence, has risen sharply in recent decades as a result of its economic development. Most of the population is made up of foreigners employed in the service and construction sectors: Indians (24\%), Nepalese (16\%), Arabs (13\%), Filipinos (11\%), Bangladeshis (5\%) and Sri Lankans (5\%) (World Population Review, 2021).

Qatar has one of the highest per capita incomes in the world (52,791 dollars per annum in 2020) and is the most advanced Arab state on the Human Development Index drawn up by the UNPD (at position 45 in 2020) (Human Development Report, 2020: 241). Its vast energy resources have enabled the $\mathrm{Al}$ Thani dynasty to establish, like other monarchies of the Gulf, a tacit social contract with its 320,000 Qatari subjects (barely $13 \%$ of the country's total population), whereby the Qataris give up any political aspirations in exchange for material considerations, since education and healthcare are free, and housing is heavily subsidized.

This energy wealth has also allowed it to implement neopatrimonial policies that have guaranteed social peace over recent decades, thanks to the partial redistribution of oil revenues among the local populations. The $\mathrm{Al}$ Thani dynasty has launched an intelligent policy of co-optation to secure the backing of the religious, economic and political elites, as well as the most influential tribes. Consequently, the preservation of such privileges is associated with the preservation of internal cohesion, the maintenance of tribal 'asabiyya and the continued existence of the dynasty.

\section{From British protectorate to alliance with the USA}

The pressing need to forge solid alliances with international powers that can guarantee its security derives from the fact that Qatar is one of the smallest and least populated countries in the Gulf, and so extremely vulnerable as a State. In 1916, with the imminent collapse of the Ottoman Empire, Qatar signed a defence treaty with Great 
Britain which committed the British government to protect the Al Thani dynasty, its subjects and territories from any aggression. It should be noted that the treaties and capitulations that the British imposed on each of the emirates in the Persian Gulf constituted "the genesis of the Gulf states as separate political units" (Ayubi, 1998: 132).

Qatar also approached Saudi Arabia, the major Arab regional power on the Arabian Peninsula, to ensure its defence. At the beginning of the twentieth century, Emir Jassim bin Mohammed Al Thani not only recognized the Wahhabi rite as the official one in Qatar, but also agreed to pay a tribute to Abdul Aziz Al Saud. Even after signing a defence agreement with Great Britain in 1916, the Thanis continued to pay the tribute to the Al Saud. Nonetheless, the 'Wahhabism of the sea' practised in Qatar was much more open than the 'Wahhabism of the desert' that prevailed in Saudi Arabia (Fromherz, 2012: 93), among other reasons because Qatar's economy was based on trade with its neighbours, which required it to maintain fluid relations with Shia Iran. In Rosemarie Said Zahlan's opinion, it was "the absence of inland settlements [that] made Qatar dependent commercially and politically on its neighbours" (Zahlan, 1979: 14).

With Emir Khalifa bin Hamad Al Thani (1972-1995), the relationship with Saudi Arabia continued to be one of dependency, understood in the sense of Holsti as "a situation where the 'smaller' state can act in its domestic and/or external policies only with the implicit or explicit consent of another state, and where the capacity to threaten or reward in the relationship is highly asymmetrical" (Holsti, 2016: 109).

The Iran-Iraq war (1980-1988) showed that the old territorial tensions had not been forgotten but had created new disputes in a region with new political realities and new economic ambitions. The Iraqi invasion of Kuwait in 1990 created a shock wave among the Gulf monarchies that accelerated the strengthening of relations with the USA. Like other Gulf countries, in 1992, Qatar signed a Defense Cooperation Agreement with the U.S. that provided for U.S. access to Qatari bases and pre-positioning of U.S. military materiel on them.

After the attacks of September 11th 2001, the alliance with Saudi Arabia began to be openly questioned in American political circles and Qatar's standing rose significantly. In the years that followed, Qatar built the Al Udeid air base, which has been the site of the forward headquarters of Central Command (CENTCOM) since 2009. Nevertheless, its close relationship with the United States has not prevented Qatar from developing its own foreign policy, which took a critical line on U.S. sanctions against Iraq, the isolation of Iran and support for Israel (Baabood, 2007: 163).

\section{The Gulf Cooperation Council: a failed project}

The triumph of the Islamic Revolution in 1979 was viewed with alarm by the petro-monarchies in the Gulf, given that the Iranian regime decided to export the Islamic revolution to all those countries in the region with Shia populations: Saudi Arabia, Kuwait, the Emirates and, especially, Bahrain (González del Miño, 2018: 738). 
For all of them, the Iranian revolution was a sharp wake-up call, because it was "a fervently anti-Monarchical, anti-Sunni, Revolutionary Shia regime, which stood accused of exporting terrorism and unrest to the Gulf States in the 1980s" (Roberts, 2017a: 42).

The approach taken by the Carter Doctrine of January $23^{\text {rd }}, 1980$ helped to calm the fears of those countries, by making it plain that the United States would intervene in the zone "by any means necessary, including military force" if it considered that its national interests were threatened. As President Carter affirmed in the State of the Union Address: "Let our position be absolutely clear: An attempt by any outside force to gain control of the Persian Gulf region will be regarded as an assault on the vital interests of the United States of America, and such an assault will be repelled by any means necessary, including military force" (Carter, 1980). On May 25 ${ }^{\text {th }}$, 1981, the Gulf Cooperation Council (GCC) was established. The Council was conceived as an instrument both to generate stability in a region that possessed almost half the world's reserves of hydrocarbons, and to guarantee the security of several small countries that felt vulnerable due to their limited military capabilities. This organization was far from functional however because "it was neither a political nor a military alliance, and [...] lacked an integrative supra-national decision-making institution” (Ulrichsen, 2014a: 23).

The concentration of hydrocarbons in the Gulf nations has, to a large extent, determined both their foreign and domestic policies. On the international stage, the petro-monarchies established solid alliances with the United States, which became the leading international power after the collapse of the Soviet Union and guaranteed their security in exchange for advantageous trade and military agreements based on the logic of "energy-for-security". At the domestic level, the same countries implemented neo-patrimonial policies based on the redistribution of resources among the population to guarantee social peace. As Ana Echagüe put it, " $[\mathrm{t}]$ he distributive nature of the Gulf economies has allowed the rulers to link the welfare of their populations to their continued stronghold on power. Regimes have further consolidated their power through large government apparatuses that exert control and facilitate patronage" (Echagüé, 2014: 2).

Nevertheless, relations among the members of the Council are far from exemplary. It should be remembered that there is a marked asymmetry between Emirates, Qatar, Bahrain, and Saudi Arabia, the country with the largest population, land area, and resources. Traditionally, Riyadh has tried to preserve its leadership in the region via subordination of the Gulf emirates. Arabia is also Sunni Islam's centre of gravity, not only because of the sanctuaries of Mecca and Medina, but also thanks to "the holy alliance between oil and religion" (Corm, 1991: 98), which has led to the spread beyond Saudi borders of Wahhabism, also known as "petro-Islam", the strict, fundamentalist form of Sunni Islam (Ayubi, 1998: 342).

Another element of tension has been the border disputes between members of the GCC, in particular those between Qatar and its neighbours. The negotiations for the demarcation of borders between 1961 and 1971 were bilateral in nature, between the United Kingdom and each of the countries in the region (Okruhlik and Conge, 1999: 233). 
This led to a situation where many countries did not recognize the borders established by the British, especially following the discovery of deposits in border areas, when tensions shifted into concerns about national security and mineral rights (ibid.: 234).

Disputes between the Gulf countries have followed different courses. While most of them have been settled through the mediation of a third state, others have had to be settled at the International Court of Justice (ICJ). In 1992, Saudi Arabia and Qatar clashed at the Al Khafus border crossing. Following this incident, Hamad Bin Khalifa Al Thani, then defence minister, suspended the 1965 agreement, causing Saudi Arabia to invade the border post. It was not until 1999 that the two countries reached an agreement, putting an end to a dispute that had dragged on for thirty-five years and concluding with a new demarcation of land and sea borders of over 60 kilometres.

The conflict between Bahrain and Qatar over the Hawar Islands was the only territorial dispute between two Arab states to be taken to the ICJ and satisfactorily resolved, thus highlighting the inability of the GCC to mediate among its member countries. The Hawar Islands are an archipelago of seventeen islands located between the coasts of Bahrain and Qatar. The largest island, Hawar, is only five kilometres off the Qatari coast, while the city of Zubarah, claimed by Bahrain, is located on the Qatari peninsula. The conflict began in 1935 when several oil companies tried to exploit the oil fields on the islands' seabed. Bahrain established a military camp on the island of Hawar, which Qatar interpreted as an attack on its sovereignty, since Doha claimed that territory as its own (Wiegand, 2012: 82). While Bahrain proposed regional mediation led by Saudi Arabia, Qatar took the issue to the ICJ, initiating a dispute that would not be resolved until 2001. A series of hostile acts ensued between the two countries in the years that followed. Finally, in March 2001, the Court established that Zubarah and the islands of Fasht Dibal and Janan would be under Qatari sovereignty, while Hawar, Qitat Jaradah and Fasht Al Azm would be for Bahrain. The decision was based on the recognition of the borders established under the British protectorate (ibid:: 87).

\section{THE RESTRUCTURING OF QATARI FOREIGN POLICY (1995-2011)}

The coming of Emir Hamad bin Khalifa Al Thani to power in 1995 prompted the restructuring of Qatar's foreign policy with the aim of breaking the ties of dependence that had existed with Saudi Arabia since the time of his father, Emir Khalifa Bin Hamad Al Thani. In an attempt to enhance Qatar's regional and international image, Emir Hamad assumed a mediator-integrator role, proposing various diplomatic and mediatory initiatives to settle regional conflicts, and promoting development cooperation and humanitarian aid, all common soft power tools.

After his enthronement, Emir Hamad bin Khalifa set in motion a process of political liberalization, the main highlights of which were the abolition of mass media censorship in 1995, dismantling the Ministry of Information in 1998, holding the first elections to elect the Municipal Council of Doha in 1999, and the adoption by 
referendum of a Constitution in 2003. Emir Hamad explained this Copernican turn as follows: "We have simply got to reform ourselves. We're living in a modern age. People log on to the Internet. They watch cable TV. You cannot isolate yourself in today's world. And our reforms are progressing well. In a tribal country like Qatar, however, it could take time for everyone to accept what we've done. But change, more change, is coming" 2 .

Qatar portrayed itself as an innovative, dynamic actor with the capacity to mediate in the various conflicts in the region, and to project itself onto the world stage thanks to the immense resources provided by its gas reserves. Recognition of its international stature was confirmed by Qatar's election to membership of the U.N. Security Council in 2006 and 2007 and the active role it played during the Arab Spring from 2011. As Ulrichsen says, "a combination of wealth and vision underpinned the success of Qatar's strategy and enabled it to eclipse the Arab world's traditional superpowers" (2014a: 37-38).

After that, Qatar's role as mediator-integrator gradually shifted to a more independent-active one, which it would fully take up in the context of the so-called Arab Spring. In the context of this new foreign policy, it employed the tools of soft power to project its image in the Arab and Islamic spheres. Examples of soft power include mediation in regional conflicts, the setting up of the pan-Arab television channel, $\mathrm{Al}$ Jazeera, and the creation of the Qatar Foundation to promote culture, education and sport as part of a state branding effort.

\section{Qatar's new foreign agenda}

The architect of this foreign policy was Emir Hamad bin Khalifa Al Thani, who can be considered responsible for creating "the modern state of Qatar", turning the emirate into "a State with a global reputation, powerful international allies, a significant regional influence and the strongest welfare state on earth" (Roberts, 2017b: 11).

The coming of Emir Hamad bin Khalifa Al Thani to power in 1995 led to a deterioration in Qatari-Saudi relations. The overthrow of Emir Khalifa, a close ally of the Saudis, created a deep sense of unease in Saudi Arabia. In the previous decade, when he was Minister of Defence and President of the Supreme Council for Planning, Hamad had already made it clear that he was committed to diversifying Qatar's regional alliances by establishing diplomatic relations with China and the Soviet Union and drew close to Iran without waiting for the green light from Saudi Arabia.

All these moves stirred up obvious unease in Saudi Arabia, which refused to treat the emirate as an equal, having long assumed that "Qatar [was] little more than a vassal state" that ought to follow Riyadh's directives (Roberts, 2016: 5). Indeed, in his first ten years in power, Hamad had to face three attempted coups against him (in

2. Quoted in Weaver, M. A. (2000). "Democracy by Decree”, The New Yorker, November 20. Available at: https://www.newyorker.com/magazine/2000/11/20/democracy-by-decree. 
1995, 1996 and 2005) in which Saudi Arabia and the United Arab Emirates were involved to varying degrees. This permanent threat pushed Qatar into establishing a firm alliance with the United States, granting the Americans the use of the Al Udeid air base, which currently hosts the CENTCOM forward headquarters.

Qatar also committed to strengthening relations with Iran. The relationship between the two countries is essentially based on pragmatism, since they both share the exploitation of the North Field / South Pars gas reservoir containing one of the largest gas deposits in the world. While it would be going too far to talk of an alliance between the two countries, it is possible to call it a privileged relationship. Qatar "has an existential interest in maintaining the security of the Gulf and limits on the expansion of potential hegemonic powers in the region" and indeed its good relations with Iran "have also served to deflect and hamper attempts by Saudi Arabia to dominate the Arab Gulf region" (Fromherz, 2012: 97, 99).

As a non-permanent member of the Security Council in 2006 and 2007, Qatar voted against resolution 1696, which imposed sanctions on Iran for developing its nuclear programme. Qatar's objective was to try to "position itself as a secret negotiator between the USA and Iran" (ibid:: 97), although in the end that role was performed later by Oman within the framework of negotiations between the G5+1 and Iran. As Khalid bin Mohammed Al-Attiyah, the former Minister of Foreign Affairs, pointed out: "Our two countries share much in common, starting with a longstanding history of trade and cultural exchange across the Gulf. I am therefore surprised and a bit saddened by the current tendency going around to create a virtual enemy. I am afraid though that these unfortunate tactics will simply go to waste. We do indeed strongly differ with our Iranian neighbour over the issue of Syria, but the State of Qatar does not consider Iran its enemy" (Al-Atiyyah, 2013: 8).

This privileged relationship with Iran did not prevent Qatar from allowing Israel to open a trade office in Doha in 1996 following the signing of the Oslo Accords between Israel and the PLO, where Emir Hamad himself was in attendance. Indeed, Shimon Peres was invited to Qatar in the summer of 1996 and Israeli leaders such as Tzipi Livni have been relatively regular participants in the Doha Forum. The normalization of relations was abruptly interrupted following the outbreak of the Aqsa Intifada, and the coming to power of Ariel Sharon in 2001. In 1999, when the Hamas offices were closed down in Jordan, Qatar offered shelter to the chief of its Political Bureau: Khaled Mashal. After the Arab Spring, Emir Hamad was the first international leader to visit the Gaza Strip on 23 October 2012, where he condemned the blockade of the Palestinian territory and promised aid to the tune of 400 million dollars.

\section{The Qatari decision-making mechanism}

Leadership style is one of the most influential determinants when it comes to determining the foreign policy of a country. The arrival in power of Emir Hamad involved a change in role conception and consequently, a review of role performance. 
In 1995, Qatar adopted a role as a mediator-integrator, which then became active and independent as Emir Hamad consolidated his power.

The turning point in Qatar's foreign policy coincided with Emir Hamad's accession to the throne in 1995 . The Qatari Constitution, which was ratified by referendum in 2003 with $98 \%$ of the votes in favour, grants broad powers to the Emir, who is Head of State (art. 64), represents the country abroad (art. 66), can impose martial law (art. 69), declare war in self-defence (art. 71) and appoint the Prime Minister (art. 72). Article 67 of the Constitution lists the Emir's specific powers: to draw up the general policy of the State with the assistance of the Council of Ministers, ratify and promulgate laws, convene the Council of Ministers, establish and organize Ministries and other Government bodies, appoint civil servants and military personnel and terminate their service in accordance with the law, among others.

Determining foreign policy is not the sole responsibility of the Emir, but also involves the Minister of Foreign Affairs. In this respect, the important role played by Hamad bin Jassim Al Thani should also be emphasized. He was in charge of the Ministry of Foreign Affairs for two decades (between 1992 and 2013) while, in 2007, he also assumed the post of Prime Minister. Both are the architects of the new foreign policy based on the use of soft power to increase Qatar's influence on the regional stage. As Ulrichsen reminds us, "these two men emerged as the architects of a strategy of aggressive internationalisation that put Qatar well and truly on the global map as a dynamic new regional actor" (2014a: 13). One of the keys to this foreign policy was “to deeply and drastically diversify Qatar's international relations, foster a reputation for the state as an impartial, almost neutral mediator, as well as one of the most dynamic, forward-thinking entrepôts in the Persian Gulf" (Roberts, 2016: 5).

As we know, "a single leader cannot make and implement foreign policy by himself or herself. In fact, in most countries, foreign policy decisions are always made in a group setting" (Hudson, 2014: 73). The new Qatar's foreign policy was highly centralized, with only a small hard core involved in its conception, which made the process of taking decisions and implementing them easier. Apart from Emir Hamad and Minister Hamad bin Jassim Al Thani, others involved in varying degrees in the decision-making process were Abdullah bin Hamad Al Attiyah, the powerful Minister of Finance and Petroleum, and the influential Sheikha Moza bint Nasser Al Missned, in charge of the Qatar Foundation for Education, Science and Community Development (Roberts, 2017a: 137). This concentration of power also marked a clear break with previous eras, when important decisions used to be taken by the leading members of the ruling family, in accordance with existing tribal customs in the region (Zahlan, 1979: 20).

The result of these strategic moves was to give Qatar an influence that was completely out of proportion its size and population and, also, to arouse the susceptibilities of Saudi Arabia and the UAE, which interpreted the rise of Qatar as a threat to their traditional leadership of the region. 


\section{The hallmarks of the new Qatari foreign policy}

The distinctive feature of the new Qatari foreign policy was, as noted, its adoption of the mediator-integrator role, employing tools of soft power such as mediation in regional conflicts, setting up the pan-Arab television channel, Al Jazeera, and the promotion of culture, education and sport through the Qatar Foundation. This intense activity goes against the realist theory of international relations, according to which small states participate less in international affairs, limit their foreign policy to their immediate geographical area, employ economic and diplomatic means instead of military instruments and usually cooperate to avoid conflict with other actors (Habraken, 2017: 2). Indeed, various analysts as Habraken have argued, "Qatar acts, or at least sees itself more like a middle power than as a small power" (ibid.: 5).

\section{a. Public diplomacy}

The first main pillar that distinguishes Qatari foreign policy is its commitment to mediation in regional conflicts. Article 7 of the Qatari Constitution expressly states that: "The foreign policy of the State is based on the principle of strengthening international peace and security by means of encouraging peaceful resolution of international disputes; and shall support the right of peoples to self-determination; and shall not interfere in the domestic affairs of states; and shall cooperate with peace-loving nations". In his address to the UN General Assembly in 2007, Emir Hamad said: "The world's major conflicts have become far too big for a single power to handle them on its own". This active involvement has been very useful to Qatar for "building its global image and gaining international recognition" (quoted by Baabood, 2017: 10-11).

Consequently, one of the main instruments of the new Qatari foreign policy has been public diplomacy, defined as the "communication and dissemination of messages by governments aimed at foreign publics with the view of creating a public discourse around a matter of concern, either influencing or informing an overseas audience" (Al Muftah, 2019: 233). Based on this, Qatar has mediated in diverse frozen conflicts, for example, in the Lebanon (2008), Yemen (2008-2010), Darfur (2008-2010), SudanChad (2009), Djibouti-Eritrea (2010) and Palestine (2012), which has helped strengthen its international image and reinforce its prestige. It should be stressed at the same time that this type of mediation also forms part of Doha's strategy to maintain links and open channels of communication, both with like-minded countries and with adversaries (Mohammadzadeh, 2017: 34-36).

b. Al Jazeera: the giant of Qatari communication

The second pillar is the satellite TV channel Al Jazeera, which has become a key element of its soft-power strategy to increase its international outreach. The channel, 
founded in 1996, became the media network with the largest audience in the Arab world. It increased Qatar's popularity considerably and was able to convert this popularity into political influence.

In a region accustomed to government censorship of official communications media and the subservience of private television channels, the emergence of a television channel that gave expression both to government sectors and critical voices caused "a regional, and indeed in some cases (as for instance on its coverage of terrorism) a global, media revolution whose repercussions are still unfolding" (Al-Jarman, 2018: 14). Al Jazeera soon became a useful tool for disseminating the Qatari narrative to the rest of the Arab world, which created distrust in the neighbouring countries, in particular Saudi Arabia, which decided to confront it in 2002 by creating the Al Arabiya channel, which also serves as a mouthpiece for Saudi-Emirati positions.

The Al Jazeera channel has led to controversy among neighbouring countries, not only because of its criticism of Gulf monarchies or the governments of the region, but also because of its coverage of certain events. After the invasion of Iraq in 2003, Al Jazeera was one of the most critical voices against the US in the region, even being described by US officials as "an anti-American network" (Fromherz, 2012: 122). During the Arab Spring, Al Jazeera served as a loudspeaker for the protests, which led to the escalation of tension with Saudi Arabia and the Emirates, which were in favour of maintaining the regional status quo. The militant coverage given by the Qatari network to the coup d'état staged against the Muslim Brotherhood in Egypt in 2013 with Saudi Arabian and UAE support represented the peak moment of this tension, which triggered the withdrawal of the ambassadors of Saudi Arabia, the UAE and Bahrain from Doha in 2014.

\section{c. The Qatar Foundation and the internationalization of education}

The third main strategy projecting a positive image of Qatar on an international scale is its promotion of culture, education and sport through the Qatar Foundation for Education, Science and Community Development in line with the Qatar National Vision 2030. This foundation was set up in 1995 by the second wife of Emir Hamad, Sheikha Moza bint Nasser Al Missned. Her main aim is to train the new Qatari generations in the fields of education, science and research, but also to attract talent and consolidate the country as an international centre for research and development.

Sheikha Mozah played a leading role in the country's educational reform, placing emphasis on the need to empower Qatari women, whose situation has improved markedly in recent decades. Whereas in the past, education was reserved for men, and women were confined to the domestic sphere (Bahry and Marr, 2005), at present, $42 \%$ of university graduates are accounted for by women compared to $25 \%$ of Qatari men (Planning and Statistics Authority, 2019).

The creation of the Qatar Foundation and Education City have been the two major projects of Sheikha Mozah. The main objective of the Qatar Foundation is "to support Qatar in its journey from the carbon economy to the knowledge economy, 
unlocking human potential" ${ }^{3}$ based on three pillars: education, research and community development. The Foundation has a campus in Doha that is home to several foreign universities (among them, Georgetown University School of Foreign Service, Northwestern University, Virginia Commonwealth University, Weill Cornell Medicine, Texas A\&M University, Carnegie Mellon University, HEC Paris and University College London), as well as the recently opened Qatar National Library.

The momentum provided by the Qatar Foundation and Education City, along with mediation and diplomacy, has become one of the branches of Qatari state branding. A state-branding is a survival technique used by several small countries to differentiate themselves, whether in a region or internationally (Peterson, 2006). Other Gulf countries have developed their own strategies to achieve both visibility and influence in the region. The UAE opted for the development of luxury tourism and mega-developments in Dubai, while the aim of Abu Dhabi is to establish itself as a cultural centre competing directly with Doha, which set up the Museum of Islamic Art, the Museum of Modern Art and the National Museum of Qatar. Another of the objectives of state branding is to attract major sporting events. In 2010, after a vote that was not without controversy, Qatar was selected to host the FIFA World Cup in 2022.

\section{THE ROLE OF QATAR IN THE ARAB SPRING}

As we have already pointed out, our hypothesis is that the so-called Arab Spring forced Qatar and the rest of the monarchies in the Gulf to restructure their foreign policies. The Arab Spring was viewed with alarm by most of the Gulf States, but not all of them. While Qatar considered that it represented an opportunity to gain greater influence on the Arab stage, the rest of its neighbours viewed the movement as an existential threat because of its demands for reforms and freedoms. The destabilization of the Middle East and North Africa created the conditions for most States in the region to review role performance, which adopted more active roles.

During this period, Qatar completed its change of direction towards an active-independent role. According to Holsti, "this role conception emphasizes at once independence, self-determination, possible mediation functions, and active programs to extend diplomatic and commercial relations to diverse areas of the world". Similarly, "foreign policy decisions will be made to serve national interests rather than the interests of others" and "active efforts to cultivate relations with as many states as possible and occasional interposition into bloc conflicts" (Holsti, 1970: 262). As part of the restructuring of its foreign policy, the soft power tools used previously are tending to be abandoned and others more appropriate to hard power are being adopted, such as maximization of its economic capabilities, establishing aid programmes for its allies and supporting armed militias in Syria and Libya wars.

3. Qatar Foundation. 2020. About Us. Qatar Foundation. Available at: https://www.qf.org.qa. 


\section{The GCC and the Arab Spring}

Oddly enough, even though Qatar viewed the Arab Spring as an opportunity to increase its influence on the Arab stage, it continued, like other neighbouring countries, to be an authoritarian State where the Emir enjoys practically unlimited powers. The main difference is that the social contract between the Emir and his subjects is reinforced by the country's energy wealth and the fact that the Emirate is far from being a police State. Furthermore, Qatar enjoys various comparative advantages over its neighbours, since "its political stability is rooted in the country's comparative social cohesion (lack of sectarian tensions as in Bahrain and Saudi Arabia) its unitary polity and small size (compared to the United Arab Emirates and Oman) and a relatively apolitical small national population (compared to Kuwait)" (Kamrava, 2013: X).

In the early stages of the Arab Spring, Qatar "played a vital role not only in shaping the emerging narratives of protest, through the Doha-based Al Jazeera network, but also in mobilising Arab support, initially for the NATO-led intervention in Libya in March 2011, and later for the diplomatic isolation of Bashar Al-Assad's regime" (Ulrichsen, 2014a:1). The Qatari attitude towards the popular mobilizations in Bahrain and Yemen was quite different, since Doha continued to cooperate with the rest of the members of the GCC by recognizing the central role of Saudi Arabia in those two neighbouring countries as well as "the potential threat that successful uprisings in the Gulf could pose to stability in its neighborhood" (Ulrichsen, 2014b: 8).

For most of the member states belonging to the GCC, the demands for freedom and social justice of the Arab Spring posed a clear threat. Baabood wrote that "these seismic changes in the Arab world created new geopolitical dynamics, regional instability and great uncertainty, in turn posing an enormous security challenge for the Gulf States" (Baabood, 2014: 42). Whereas Qatar actively intervened in Egypt, Tunisia, Libya and Syria in favour of the Muslim Brotherhood, Saudi Arabia provided a safe haven for the Tunisian dictator, Ben Ali, and did everything it could to prevent the fall of the Egyptian president, Hosni Mubarak.

On the external front, the members of the GCC adopted a counterrevolutionary agenda. If the political transitions led by Islamist parties turned out to be successful, they might set a precedent and create a domino effect. Baabood's opinion was that "the GCC states found themselves surrounded by a political Islam that could challenge their legitimacy and undermine their traditional monarchical system" (ibid.: 44). For Saudi Arabia there could be no more dangerous enemy because "the rise of the Muslim Brotherhood in Egypt was viewed by Saudi Arabia as a challenge to its state identity and claim to the leadership of the Muslim Ummah" (Ehteshami and Muhammadi, 2017: 4).

\section{The alliance with the Muslim Brotherhood}

One of the pillars of Qatar's foreign policy is its backing of the Muslim Brotherhood. This organization enjoys considerable prestige in Egypt and other countries in 
the Middle East, which has enabled Qatar to broaden its outreach. The fact that these links are not new should not be overlooked, given that Qatar has been the home since 1961, before its independence, of the influential preacher Yusuf al-Qaradawi, who has a programme with a sizeable audience on Al Jazeera. Qatar has also welcomed other notable leaders of the Brotherhood persecuted by the Egyptian regime. They subsequently played a prominent role in setting up Qatari educational institutions, despite the fact that the country follows the Hanbali school and professes Wahhabism.

The alliance with the Brotherhood allowed Qatar "to augment its regional status, with Brotherhood ideology being more widespread than Wahhabi thought" (Roberts, 2015: 26). This relationship was mutually beneficial for both actors as long as the red lines drawn up by Doha were respected and the Brotherhood confined itself to the regional arena, not the local one. Indeed, the Islamist movement is regarded as "the modern proxy for the pan-Arabism of yesteryear, a pragmatic, uniting concept enlisted to agitate for change" (Roberts, 2017a: 138).

Qatar was clearly committed to backing the Muslim Brotherhood, not only in the processes of political change initiated in Tunisia and Egypt, but also in Libya and Syria, countries plunged into spiralling conflict. In the first two cases, Qatar backed the two main Islamist parties in Tunisia and Egypt: Rachid Ghannuchi's Ennahda and Mohammed Morsi's Freedom and Justice. Both won comfortably in the legislative elections held in 2011 and so were able to form governments led by Hamadi Jebali and Mohammed Morsi respectively. Both leaders had to contend with a strong domestic response from counter-revolutionary sectors with Saudi Arabian and Emirati backing. In view of the growing social fracture, Jebali resigned in Tunisia in March 2013 to make way for a government of technocrats, while Morsi was overthrown by a military coup in July of the same year.

In Libya, Qatar opted for the Tripoli-based General National Congress, in which the Muslim Brotherhood had a leading role, and which also had the support of Turkey. On the ground it clashed with Khalifa Haftar's National Liberation Army, based in Tobruk, which was backed by Russia, the UAE and Egypt during the second civil war in 2014 (Gutierrez de Terán, 2015: 143-167). In the case of Syria, Qatar played a double game, as it initially backed the Syrian National Council, which was controlled by the Muslim Brotherhood, but then gradually shifting its support to different Islamist militias such as Tahrir al-Sham and Ahrar al-Sham, dominant groups in the rebel province of Idlib.

Qatar's transition from a mediator-integrator role to an active-independent one was not without risk. While Emir Hamad was skilful in projecting Qatar as a regional power, he paid a high price for it, distancing himself from his traditional GCC partners and clashing head-on with Saudi Arabia and the UAE. Furthermore, his decisive involvement in the Arab Spring marked his passage "from mediator to actor and from actor to activist" and weakened his position, since he was perceived as an actor who had abandoned the neutrality that had characterized him in the past and was openly positioning himself (Roberts, 2017a: 123). 


\section{THE IMPOSITION OF THE BLOCKADE}

After acceding to the throne on June 25th 2013, Emir Tamim attempted to readjust Qatari foreign policy. The new Emir also adopted a more pragmatic, less interventionist, policy in regional affairs in an attempt to calm the waters, for while Doha intended "to maintain its autonomy in foreign policy making, it would seek to take a more cooperative and multilateral approach that [was] less overtly ideological than in the past" (Ulrichsen, 2014b: 20). He also decided to replace the prime minister, Hamad bin Jassim Al Thani, with Abdullah bin Nasser Al Thani, and appointed Khalid bin Mohammed al-Attiyah as Minister of Foreign Affairs.

\section{From the tensions of 2014 to the blockade of 2017}

This turnaround did nothing to resolve the disputes with some of its neighbours. In fact, on March 5th 2014, Saudi Arabia, the United Arab Emirates and Bahrain announced the withdrawal of their ambassadors from Qatar, accusing the country of interfering in the domestic affairs of the GCC member States. That same day, the trial of 94 members of the Emirati Islamist movement al-Islah opened and the defendants were charged with preparing a coup d'état. Just two days later, Saudi Arabia and the Emirates declared the Muslim Brotherhood a "terrorist group", equating it with jihadist formations such as the self-styled Islamic State and Al Qaeda, and, at the same time, banning their nationals from financing or supporting it. Even though diplomatic relations returned to normal a few months later, relations between the GCC member States were seriously undermined as a result of this episode (Stephens, 2017: 11).

Proof of this is that, on June 5th 2017, the so-called Quartet comprising Saudi Arabia, the United Emirates, Bahrain and Egypt decided to go one step further and impose a land, sea, and air blockade on Qatar, which would only be lifted once Qatar had complied with a long list of conditions. Behind this radical measure were the Crown Princes of Saudi Arabia and the United Arab Emirates, Mohammed bin Salman and Mohammed bin Zayed. In the following weeks, other Arab States joined the Arab Quartet, among them Jordan, Mauritania and the governments of Abd Rabbuh Mansur al-Hadi in Yemen, and of Khalifa Haftar in Libya.

One of the main demands was to close down Al Jazeera, accused of interfering in Arab politics; another was to cut off finance to the Muslim Brotherhood, which was branded a terrorist organization. The Quartet also accused Qatar of destabilizing the region by financing jihadist groups like the Al Nusra Front or Al Qaeda. Lastly, the Quartet insisted that Qatar should sever its relations with Iran and leave the orbit of Turkey, which were also trying to export their own version of political Islam and so were competing with Saudi Arabia.

The blockade placed Qatar in an extremely delicate situation. Apart from breaking off diplomatic relations, the member States of the Quartet also decreed the closure of 
its land, sea, and air space, which triggered a shortage of essential goods. Since Qatar imports $90 \%$ of the foodstuffs it consumes, half of which enter the country via the land border with Saudi Arabia, alternative routes through Turkey, Iran and Oman had to be found.

\section{The split in the GCC}

The Saudi Arabian and Emirati Crown Princes, Mohammed bin Salman and Mohammed bin Zayed, played a central role in planning and executing the blockade of Qatar. In the last years, the relationship between the Princes has strengthened, as demonstrated by the formation of a new military, economic and cultural partnership on December 5th 2017 between the Emirates and Saudi Arabia. Both Princes agree on the need to join forces to address what they consider to be the two main threats looming over their countries: Iran and the Muslim Brotherhood, with which Qatar has a close relationship (Quilliam, 2019: 120).

The objective of Mohammed bin Salman and Mohammed bin Zayed was to lay down red lines that should under no circumstances be crossed by the rest of the GCC member States: "The pressure that has been exerted on Qatar is not an isolated effort; it is a part of a larger scale planning to shape the future order of the region" (Köse and Ulutas, 2017: 1). Qatar's role in the Arab Spring has split the GCC into two groups: the first, consisting of Saudi Arabia, the Emirates and Bahrain, is in favour of adopting an interventionist policy in the region to try and stop the advance of Iran, the second, comprising Qatar, Kuwait and Oman, advocates dialogue to resolve regional crises.

The ultimatum failed to change Qatar's foreign policy, which adapted to the new situation by establishing ties with key actors in the region (especially Iran and Turkey). Qatar seems to have come out of the blockade all the stronger. To quote Baabood, "the recent blockade of Qatar by the Quartet has clearly demonstrated its vulnerability but also the success of its resilience strategy. Qatar has been able to withstand the negative harmful effects of the blockade and has been able to win measurable political and economic support from international as well as regional countries" (Baabood, 2017: 21).

The role of international powers has been key in ensuring that the crisis did not escalate. From the outset, Qatar set in motion "a damage limitation strategy" aimed at rallying international backing and exploiting differences in the Trump Administration. ${ }^{4}$ As a result of this, the United States and the European Union advocated a negotiated solution to the crisis. The USA's position was probably influenced by the fact that Qatar is the site of CENTCOM's forward headquarters and by Qatar's announcement of a deal to purchase weapons and F-15 fighter jets for twelve billion dollars. In Europe, Germany and France have stood firm in seeking a diplomatic outcome to the crisis.

4. Personal interview with Azmi Bishara, director of the Arab Center for Research and Policy Studies and personal advisor to Emir Tamim, conducted in Doha on 30 April 2018. 


\section{Turkey and Iran in the new regional scenario}

The blockade was not only intended to call Qatar to order but was also part of a plan to reshape the region. Some even argued "that Turkey [was] the real target and Qatar [...] just a diversion" (Aras and Akpinar, 2017: 3). Turkey could also be accused by the Quartet of backing the Muslim Brotherhood, maintaining good neighbourly relations with Iran and supporting certain jihadist groups in the Syrian conflict, the arguments used to justify blockading Qatar.

Since the beginning of the Arab Spring, Qatari-Turkish relations have strengthened considerably. Apart from cooperating actively in Syria and Libya, the two countries signed a military cooperation agreement in 2014 that enabled the first Turkish base outside its borders to be opened two years later. In fact, the then Turkish Prime Minister Ahmet Davutoglu addressing students at the University of Qatar in 2016 stated that: "The security and stability of Qatar is like the security and stability of Turkey. We want a stable and secure Gulf. Turkey and Qatar, we have the same destiny. We face the same threats"s.

With the escalation of tension between Russia and Turkey also in 2016, Qatar offered to supply gas to Turkey and aid amounting to 3 billion dollars to deal with its economic crisis. After the blockade was imposed on Qatar, the Turkish parliament authorized 3,000 soldiers to be deployed in the emirate to "protect Qatar from a potential coup d'état" (Gurbuz, 2017: 1). With this action, President Erdoğan sent a clear message to the boycotting countries and the region as a whole: Turkey would defend its ally, by military means if necessary (Bakir, 2019: 213). In this way, Turkey demonstrated that it could position itself as a reliable ally in times of crisis using a combination of soft and hard power.

The blockade also strengthened relations between Qatar and Iran. When the GCC crisis erupted, "Iran quickly decided to prioritise its confrontation with Saudi Arabia, moving to support Qatar in the intra-GCC dispute in order to weaken Riyadh and enhance Tehran's regional leverage" (Zaccara, 2019: 6). Tehran sent the Arab emirate 350 tonnes of food by air and sea, thus opening up air and sea corridors to secure its food supplies (Boussois, 2019: 228). At the same time, Iran offered its air space so that Qatar Airways, one of the world's leading airlines, could continue to operate. In return, Iran has obtained economic and political benefits from this crisis, since the trade agreements between Tehran and Doha for the import of food and hydrocarbons have enabled the Iranian regime to mitigate the effects of US sanctions. Moreover, "by presenting itself as a reliable partner in this blockade, Iran has managed to diversify its alliances and improve its relations with other neighbouring countries such Iran sided with Qatar, using a very pragmatic approach that prioritised long-term confrontation with Saudi Arabia" (Zaccara, 2019: 12).

5. Reuters, 2018. “Seeing Shared Threats, Turkey Sets Up Military Base in Qatar”, Reuters, 28 April. Available at: https://es.reuters.com/article/idUSKCNOXP2IT. 


\section{The normalization of relations with Israel and the end of the blockade}

On September 15th 2020, the United Arab Emirates and Bahrain normalized their relationship with Israel in a solemn ceremony held at the White House. The mediation of the US administration was decisive in the normalization process, although relations between Israel and the Gulf countries were an open secret. All players are united by their desire to counter Iranian expansionism in the Middle East. While Bahrain is a tiny emirate with hardly any influence to speak of, the United Arab Emirates is a military power with huge regional influence and indeed, is one of the world's leading arms importers, which has enabled it to adopt an interventionist foreign policy in Yemen and Libya, where it has deployed troops to try to curb its regional rivals: Iran, Qatar and Turkey.

From now on, the major unknown is the position of Saudi Arabia. Although Riyadh has given the green light to the normalization of relations with Israel, it does not appear willing to take such a large step itself. Whereas the new generation led by Crown Prince Muhamad Bin Salman is in favour of cooperation with Israel, the old guard led by King Salman is clearly against it, owing to the possible costs that might ensue, not only on the regional stage but also at home. The normalization agreement has caused discomfort among some Arab countries as Qatar, which indicated in an official statement that "Qatar will spare no effort to provide all the support it can to alleviate the suffering of the Palestinian brothers until the Palestinian people obtain all their legitimate rights" ${ }^{\text {. }}$.

At the end of 2020, rumors about the Gulf countries' intention to resolve the political crisis with Qatar. On December 27th, the foreign ministers of the GCC countries met virtually to establish a roadmap to resolve the conflict at the council's annual summit in January 2021. The summit, which was held in Riyadh, concluded with the signing of the Al-Ula Declaration, ending a four-year blockade to Qatar. Saudi Arabia's pressure to end the disagreement with Doha responds to the need to reduce tensions with the Biden administration, which has said it would review bilateral relations with Riyadh.

\section{CONCLUSIONS}

The arrival of Hamad Bin Khalifa Al Thani in 1995 marked a turning point in Qatar's foreign policy, as a result of which the ties that had kept it dependent on Saudi Arabia were broken and it adopted a much more autonomous mediator-integrator role. As part of this restructuring process, Qatar presented itself as a dynamic player, at both regional and international levels. The development of public diplomacy, the growing influence of the Al Jazeera channel and the promotion of knowledge, education and culture by the Qatar Foundation were the hallmarks of this new foreign policy, thanks to which Qatar has projected a positive international image of itself.

6. Ministry of Foreign Affairs of Qatar. 2020. Qatar Affirms Its Firm Position on Palestinian Issue. Available at: https://cutt.ly/cmR3wvN. 
As it was pointed out at the beginning of the article, our hypothesis was that the Arab Spring forced Qatar and the rest of the monarchies in the Gulf to restructure their foreign policies. After the anti-authoritarian mobilizations, most of the Gulf monarchies opted to shield themselves from the winds of change blowing through the Middle East and North Africa. Qatar took advantage of the situation to increase its presence and influence in the Arab regional arena by assuming a more active and independent role. This shift from a mediating role to an active one also entailed abandoning the tools of soft power and adopting instruments more suited to hard power, as evidenced by its backing of various armed militias in Syria and Libya.

As Hudson points out, "every foreign policy decision is meant to achieve its aims; however, complete success is extremely rare, and there is a spectrum of achievement ranging from mostly successful to unintentionally provoking the precise opposite reaction to what was anticipated or intended" (Hudson, 2014: 6). The restructuring of Qatar's foreign policy involved conflict with several GCC members, particularly Saudi Arabia and the UAE. The land, sea and air blockade in 2017 revealed the extent of the rift as a result of Qatar's adoption of an independent role. The ultimate aim of this blockade was to encourage Qatar to revise its foreign policy, though the result appears to have been otherwise, since Doha has responded by strengthening its relations with Turkey and Iran, precisely the two main regional rivals of Saudi Arabia and the Emirates.

The normalization of relations between Israel, Emirates and Bahrain in September 2020 was motivated by the common will to counter Iranian expansionism in the Middle East. The mediation of the Trump administration was decisive in this normalization process, although relations between Israel and the Gulf countries were an open secret. Few months later, GCC countries signed the Al-Ula Declaration, ending the four-year blockade. Saudi Arabia's pressure to end the disagreement with Doha, responds to the need to reduce tensions with the new Biden administration.

\section{References}

Aggestam, Lisbeth. 2006. "Role Theory and European Foreign Policy: a Framework of Analysis", in Ole Elgeström and Michael Smith (eds.), The European Union's Roles in International Politics: Concepts and Analysis. Oxford: Routledge.

Alden, Chris and Amnon Aran. 2017. Foreign Policy Analysis: New Approaches. London: Routledge. Available at: https://doi.org/10.4324/9781315442488.

Al Muftah, Hamad. 2019. "Qatar's Response to the Crisis: Public Diplomacy as a Means of Crisis Management”, in Andreas Krieg (ed.), Divided Gulf: The Anatomy of a Crisis. London: Palgrave Macmillan. Available at: https://doi.org/10.1007/978981-13-6314-6_14.

Al-Attiyah, Khalid B. M. 2013. Qatar's Foreign Policy. Chatham House.

Al-Jarman, Mohammed. 2018. "American Policy Dissonance on the 2017 Gulf Crisis”. Global Policy, 30-1-2018. Available at: https://cutt.ly/ImRMLuH. 
Aras, Bülent and Pinar Akpınar. 2017. Turkish Foreign Policy and the Qatar Crisis. Istanbul Policy Center. Available at: https://cutt.ly/OmR1wS8.

Ayubi, Nazih. 1998. Política y sociedad en Oriente Próximo: la hipertrofia del Estado árabe. Barcelona: Edicions Bellaterra.

Baabood, Abdallah. 2007. "Dynamics and Determinants of the GCC States' Foreign Policy, with Special Reference to the EU", in Gerd Nonneman (ed.), Analyzing Middle East Foreign Policies and the Relationship with Europe. London: Routledge.

Baabood, Abdallah. 2014. "Gulf Countries and Arab Transitions: Role, Support and Effects”, IEMed Mediterranean Yearbook, 2014: 42-47.

Baabood, Abdallah. 2017. Qatar's Resilience Strategy and Implications for State-Society Relations. Working Papers, 17. Istituto Affari Internazionali.

Bahry, Louay and Phebe Marr. 2005. "Qatari Women: A New Generation of Leaders?", Middle East Policy Council, 12 (2): 104-119. Available at: https://doi. org/10.1111/j.1061-1924.2005.00205.x.

Bakir, Ali. 2019. "The evolution of Turkey-Qatar relations", in Andreas Krieg (ed.), Divided Gulf: Anatomy of a crisis. London: Palgrave Macmillan. Available at: https://doi.org/10.1007/978-981-13-6314-6_12.

Boussois, Sébastien. 2019. "Iran and Qatar: A Forced Rapprochement", in Andreas Krieg (ed.), Divided gulf: The Anatomy of a Crisis. London: Palgrave Macmillan. Available at: https://doi.org/10.1007/978-981-13-6314-6_13.

Calduch, Rafael. 1993. Dinámica de la sociedad internacional. Madrid: Centro de Estudios Ramón Areces.

Cantir, Cristian and Juliet Kaarbo. 2012. "Contested Roles and Domestic Politics: Reflections on Role Theory in Foreign Policy Analysis and IR Theory", Foreign Policy Analysis, 8 (1): 5-24. Available at: https://doi.org/10.1111/j.1743-8594.2011.00156.x.

Carter Jimmy. 1980. State of the Union Address 1980, January 23. Jimmy Carter Library. Available at: https://cutt.ly/BmR0opM.

Corm, Georges. 1991. Le Proche-Orient éclaté (1956-1991). Paris: Gallimard.

Echagüé, Ana. 2014. Emboldened Yet Vulnerable: The Changing Foreign Policies of Qatar and Saudi Arabia. FRIDE Working Papers, no 123.

Ehteshami, Anoush and Mohammadi Ariabarzan. 2017. Saudi Arabia's and Qatar's Discourses and Practices in the Mediterranean. CIDOB Working Papers, no 6.

Evans, Randy W. 2001. Japan's Regional Multilateralism: National Role Conceptions, $A P E C$, and the Nakayama Proposal [thesis]. University of British Columbia.

Fromherz, Allen J. 2012. Qatar: A Modern History. London: I. B.Tauris.

González del Miño, Paloma. 2018. "La competitividad geoestratégica Irán-Arabia Saudí en Oriente Medio. Rivalidad entre potencias regionales", Política y Sociedad, 55 (3): 733-753. Available at: https://doi.org/10.5209/POSO.58321.

Gurbuz, Mustafa. 2017. "Turkey and the Gulf Crisis: Erdoğan's Most Difficult Game?”. Arab Center, 19-6-2017. Available at: https://cutt.ly/6mR0JCQ.

Gutiérrez de Terán, Ignacio. 2015. "Libia: la transición sin Estado", in I. Álvarez-Ossorio (ed.), La Primavera Árabe revisitada. Reconfiguración del autoritarismo y recomposición del islamismo. Pamplona: Thomson Reuters Aranzadi. 
Habraken, Koen. 2017. The Case of Qatar: Understanding the Emirate's Exceptional Foreign Policy. Leiden: Leiden University. Available at: https://openaccess.leidenuniv.nl/handle/1887/53181.

Holsti, Kal J. 1970. "National Role Conceptions in the Study of Foreign Policy”, International Studies Quarterly, 14 (3): 233-309. Available at: https:/doi. org/10.2307/3013584.

Holsti, Kal J. 2016. A Pioneer in International Relations Theory, Foreign Policy Analysis, History of International Order, and Security Studies. New York: Springer. Available at: https://doi.org/10.1007/978-3-319-26624-4.

Hudson, Valerie M. 2014. Foreign Policy Analysis: Classic and Contemporary Theory. Maryland: Rowman and Littlefield.

Human Development Report. 2020. The next frontier. Human development and the Anthropocene. New York: United Nations Development Programme.

International Monetary Fund. 2019. Qatar. IMF Country Report No. 19/147.

Kamrava, Menhran. 2013. Qatar. Small State, Big Politic. New York: Cornell University Press.

Köse, Talha and Ufuk Ulutas. 2017. Regional Implications of the Qatar Crisis: Increasing Vulnerabilities. SETA Perspective, no 31. Available at: https://cutt.ly/fmR20KU.

Middle East Monitor. 2020. "Qatar Investment Authority: More than half of assets invested in private and public equity", Middle East Monitor, 17-10-2020. Available at: https://cutt.ly/6mR9pU9.

Mohammadzadeh, Babak. 2017. "Status and Foreign Policy Change in Small States: Qatar's Emergence in Perspective”, The International Spectator, 52 (2): 19-36. Available at: https://doi.org/10.1080/03932729.2017.1298886.

Morin, Jean-Frédéric and Jonathan Paquin. 2018. Foreign Policy Analysis: A Toolbox. Cham: Palgrave Macmillan. Available at: https://doi.org/10.1007/978-3-319-61003-0.

Okruhlik, Gwenn and Patrick J. Conge. 1999. "The Politics of Border Disputes: On the Arabian Peninsula", International Journal, 54 (2): 230-248. Available at: https://doi.org/10.1177/002070209905400203.

Peterson, J. E. 2006. "Qatar and the World: Branding for a Micro-State", The Middle East Journal, 60 (4): 732-748. Available at: https://doi.org/10.3751/60.4.15.

Planning and Statistics Authority. 2019. Education in Qatar Statistical Profile. Available at: https://cutt.ly/7mTt8lM.

Qatar. General Secretariat For Development Planning. 2008. Qatar National Vision. Available at: https://cutt.ly/zmR3VJ7.

Quilliam, Neil. 2019. “The Saudi Dimension: Understanding the Kingdom's Position in the GulfCrisis", in Andreas Krieg (ed.), Divided Gulf: The Anatomy of a Crisis. London: Palgrave Macmillan. Available at: https://doi.org/10.1007/978-981-13-6314-6_7.

Roberts, David B. 2015. "Qatar's Strained Gulf Relationships”, in The New Politics of Intervention of Gulf Arab States. Middle East Center-London School of Economics, Collected Papers, 1: 23-31.

Roberts, David B. 2016. “The Four Era of Qatar's Foreign Policy”, Comillas Journal of International Relations, 5: 1-17. 
Roberts, David B. 2017a. Qatar: Securing the Global Ambitions of a City State. London: Hurst and Company.

Roberts, David B. 2017b. Securing the Qatari State. Issue Paper, no. 7. The Arab Gulf States Institute. Available at: https://cutt.ly/EmR80sz.

Stephens, Michael. 2017. "Why key Arab countries have cut ties with Qatar and what Trump had to do with it", The Qatar Crisis, 12: 42-43.

Ulrichsen, Kristian. C. 2014a. Qatar and the Arab Spring. Oxford: Oxford University Press.

Ulrichsen, Kristian. C. 2014b. Qatar and the Arab Spring. Policy Drivers and Regional Implications. Carnegie Endowment for International Peace. Available at: https:// cutt.ly/pmR4Wvm.

Wiegand, Krista E. 2012. "Bahrain, Qatar, and the Hawar Islands: Resolution of a Gulf Territorial Dispute", The Middle East Journal, 66 (1): 78-95. Available at: https://doi.org/10.3751/66.1.14.

World Population Review. 2021. Qatar Population 2020. Available at: https://worldpopulationreview.com/countries/qatar-population.

Zaccara, Luciano. 2019. Iran and the Intra-GCC Crisis: Risks and Opportunities. IAI, no. 19. Istituto Affari Internazionales.

Zahlan, Rosemary. S. 1979. The Creation of Qatar. London: Routledge.

Presented for evaluation: October $20^{\text {th }}, 2020$.

Accepted for publication: June $14^{\text {th }}, 2021$.

\section{IGNACIO ÁLVAREZ-OSSORIO}

ialvarezossorio@ucm.es

Profesor titular de Estudios Árabes e Islámicos en la UCM. Entre 1999-2019 fue profesor en la Universidad de Alicante, donde dirigió el Instituto Interuniversitario de Desarrollo Social y Paz entre 2017-2019. Sus líneas de investigación se centran en la historia contemporánea de Oriente Próximo y en los procesos de cambio político. Ha dirigido tres proyectos de investigación de $\mathrm{I}+\mathrm{D}$ y publicado una docena de libros, como autor o coautor, centrados en la cuestión palestina, el conflicto sirio, la sociedad civil y las Primaveras Árabes.

\section{LETICIA RODRÍGUEZ}

Graduada en Ciencias Políticas y Gestión Pública por la Universidad del País Vasco y máster en Estudios de la Unión Europea por la Universidad de Salamanca. En la actualidad realiza su tesis doctoral sobra la política exterior de Qatar en el Departamento de Ciencias Políticas de la Universidad de Granada. Sus principales líneas de investigación giran en torno a la política comparada, análisis de políticas públicas y la sociología del poder. Es coautora del informe Desmontando el falso mito del problema migratorio (Fundación Alternativas, 2019). 